\title{
LITERATURA A FOLKLÓR
}

УДК 82.0

DOI: $10.24045 / f v .2017 .3 .5$

\section{Е. И. ЗАМЯТИН-ПИСАТЕЛЬ В ЛИЧНОЙ ПЕРЕПИСКЕ, ДНЕВНИ- КАХ И ВОСПОМИНАНИЯХ ЛИТЕРАТОРОВ-ЛЕНИНГРАДЦЕВ}

\author{
Т. Т. Давыдова \\ Доктор филологических наук, профессор \\ Московский политехнический \\ университет \\ 2. Москва, Россия
}

\section{E. I. ZAMYATIN-THE WRITER IN THE LENINGRAD'S AUTHORS CORRESPONDENCE, DIARIES AND MEMOIRS}

T. T. Davydova
Doctor of Phililogical Sciences, professor

Moscow Polytechnik University

Moscow, Russia

\begin{abstract}
The article deals with the literary connections E. I. Zamyatin, famous writer and tutor of literary group "serapionov's brothers', with K. A. Fedin, one of theme, in the periods of 1920-1930 years. The article is based on the Zamyatin's and Fedin's correspondence, essays. The critics opinions about "serapionov's brothers' maître attitude and writer's manner, decided by K. A. Fedin, are cited as well as Zamyatin's arguments about Fedin personality and works. Zamyatin's forms of the popularization of Fedin creation and the evolution of the relations among Zamyatin's and K. A. Fedin's are investigated.
\end{abstract}

Keywords: literary connections; E. I. Zamyatin; “serapionov's brothers'; K. A. Fedin.

Е. И. Замятин, известный прозаик, драматург, публицист и критик, начавший свой творческий путь в 1900-е гг., был авторитетным литературным судьей для младшего поколения ленинградских литераторов. Среди них особенно примечателен К. А. Федин, любимец автора романа «Мы».

С ним Замятина связывали отношения учителя и ученика, пере- росшие в дружбу, в том числе и эпистолярную. Замятин следил за творческим развитием младшего современника, анализировал его произведения в статьях 1920-х гг. и письмах эмигрантского периода, 1930-х гг.

Как известно, дебютировавший в литературе в 1910-е гг., Федин в 1920 г. встретился с М. Горьким и послал ему свои рассказы. Горький 
посоветовал Федину держаться поближе к Дому искусств. «Там интересные люди, живые. Вот Блок, Замятин, Чуковский», «Очень хвалил талант Замятина, его ум и знания»,записал Федин советы Горького в дневнике 19.03.1920 [9, с. 143, 145]. По совету Горького Федин сблизился с писателями из литературной группы «Серапионовы братья» [см.: 29, с. 381]. Федин впоследствии высоко оценил Замятина как наставника литературной молодежи: он «был того склада художником, которому свойственно насаждать последователей, заботиться об учениках, преемниках, создавать школу» [см.: 8, c. 77]. Вместе с тем в письме А. К. Воронскому от 13 февр. 1922 г. Федин солидаризировался с мнением московского критика о замятинской прозе нач. 1920-х гг. как политически вредной: «Всецело разделяю взгляд Ваш на замятинскую «символику» дурная политика, непристойная. Жалко, конечно, что меня и других серапионовцев окружили такими пахучими цветами. <...> по беллетристике замятинского толка открывайте пальбу. Только не пристрелите, кой грех, своих» [7, с. 22-23].

Но Замятин возлагал большие надежды на талантливого молодого литератора. В рецензии на первое печатное выступление «Серапионовых братьев» он выделил как наиболее многообещающего из этой группы Федина, высоко оценил его рассказ «Сад» и творческую самостоятельность молодого прозаика: «Федин - самый прочный из них: пока еще он крепко держит в руках путеводитель с точно установленным расписанием (без опаздываний) старого реализма и знает название станции, до которой у него взят билет» [2, с. 71]. Прогноз Замятина относительно литературного будущего Федина сбылся. Федин, в свою очередь, откликался в печати на замятинские статьи.

Федин напечатал отзыв на программную замятинскую статью «Я боюсь» (опубликована: «Дом искусств», 1921, № 1) в рецензии на № 1 журнала «Дом искусств», назвав эту смелую декларацию «самым главным» в журнале [1, с. 329-330].

В 1929 г., когда велась кампания против Б. А. Пильняка и Замятина, Федин, наряду с Замятиным, был одним из руководителей ленинградского отделения Всероссийского СП. Ему как заместителю председателя этого отделения Замятин в письме из Москвы от 21.09.1929 г. поручил разъяснить на предстоящем собрании членов ленинградского отделения идейное содержание романа «Мы» и объяснить обстоятельства его публикации в «Воле России» [см.: 4, с. 82]. В знак протеста против принятой на собрании резолюции, осуждавшей Замятина и Пильняка, Федин «23 сентября <..> вышел из правления Союза, чтобы ни за что и ни под каким давлением не возвратиться» [запись в дневнике писателя // Там же. С. 94]. Вместе с тем Федин в дальнейшем стал считать поведение опального Замятина неприемлемой идеологической демонстрацией, но при этом продолжал ценить его литературный талант.

Характерна для понимания мировоззренческой позиции Федина, обусловившей его лавирование в проти- 
воборстве разных литературных групп, запись в дневнике 27.03.1931 г. по поводу внутренней политики «Издательства писателей в Ленинграде», председателем правления которого он был:

«Перед годовым собранием пайщиков Изд-ства - война мышей и лягушек. Вчера на заседании Правления Замятин подал заявление об уходе из товарищества по той причине, что привлекаемые (по неизбежности) в Правление пролетарские писатели (ЛАПП) поставили условием своего вхождения уход Замятина», «Условие это было принято, как я о том был осведомлен М. Л. Слонимским. Затем, возможно, последует требование о прекращении печатания моих работ в Издве - и это требование, конечно, тоже будет выполнено». Поэтому Замятин хочет уйти.

Это - продолжение старыхпрестарых демонстраций, которые в конце концов вредят только одному Замятину. Беда тут в том, что он превосходно понимает никчемную пустоту подобных выступлений, но остановиться не может и при каждом случае, по каждому поводу становится в позу оскорбленного рыцаря целомудрия. Вся современная литература существует на начале «компромисса». Она «допускается» при условии, если писатель безоговорочно подчиняется идеологии и «вождям» пролетарского искусства. Иначе литературы вовсе не было бы - т. е. русской «попутнической» литературы. И если Замятин не хочет принять этого ультиматума нашей эпохи, он должен не то что уйти из пайщиков изд-ва, он должен уйти из литературы. Практически дело обстоит так: уходя из изд-ва, Замятин порывает последнюю связь с «общественностью» и лишает себя всякой мыслимой в нынешних условиях товарищеской поддержки. Его уход будет истолкован «политически». Он опять и заново будет объявлен "врагом"» [5, с. 175]. Хотя Федин и убедил Замятина взять обратно свое заявление о выходе из издательства, 30.03.1931 во время перевыборов Ю. Либединский «выступил против Замятина и рачительно повторил зады о его «вредности». Собрание готовно провело в Правление список с участием трех лапповцев. Началась новая полоса короткой, но «импозантной» истории издательства» [там же, с. 176]. Осуждение Фединым независимой позиции Замятина-писателя, не желавшего подчиниться идеологическому диктату нач. 1930-х гг. и ставшего в новой историкокультурной ситуации более «правым» по взглядам, чем «попутчики», обусловило его высказывание на одном собрании Ленинградского СП о нескромности некоторых беллетристов, пишущих о том, как они относятся к революции и как революция относится к ним: «Это литература, построенная на ложном представлении о собственном значении, полная обид и признаний, в которых уже давно никто не нуждается» [3, с. 208]. «Сергеев находит, будто бы может случиться, что история подтолкнет Евг. Ив. на какойто решительный шаг, потому что положение его стало невозможно» 
[5, с. 176], - таким важным свидетельством заканчивается описание Фединым итогового в травле Замятина события, заставившего его в ноябре 1931 г. покинуть Советскую Россию.

Федин являлся одним из корреспондентов Замятина и его жены Л. Н. Замятиной в период их жизни за границей. Письма Замятина из заграницы к Федину содержат информацию о многообразной творческой деятельности их автора. Это и работа Замятина над статьями, в т. ч. о современной русской литературе [письма от 14 апр. 1932 г., Villa "Borisella" Cagnes--sur-mer (A.M.) France, Франция, и от 22 февр. 1934 г. из Парижа], а также над главным замятинским созданием в 1930-е гг. - романом «Бич Божий» [письмо от 5 авг. 1932 г., Villa "Borisella" Cagnes--sur-mer. См.: 4, c. 82-83, 85, 91]. Много ценных фактов содержится в рассказе Замятина о перипетиях постановки в Париже и Брюсселе его пьесы «Блоха» [письма от 19 ноября и 12 дек. 1933 г. из Парижа. См.: 4, с. 88, 90].

Замятин, живя в Париже, с интересом следил за творчеством Федина и популяризировал его, рекомендуя для издания за рубежом. В письме американскому слависту А. Ц. Ярмолинскому от 11 мая 1932 г. из Парижа высоко оценена «"Трансвааль" Федина, одна из его лучших повестей», которую Замятин рекомендовал для составлявшейся Ярмолинским антологии русской советской прозы [10, с. 153].

Друзья увиделись после двухлетней разлуки в конце 1933 г. в Париже. Хлопоты по получении ви- зы для поездки Федина во Францию взял на себя живший в то время в Париже Замятин. Несмотря на приязнь к Замятину, у Федина продолжали оставаться с ним серьезные идейные разногласия, прежде всего по поводу отношения к революции, которую Федин принимал. Федину была чужда философская сложность замятинского отношения к проблеме революции как к некоему космическому феномену, он требовал от мэтра однозначного ответа на вопрос, что значит революция для политической жизни России. «Боюсь, что этот вопрос, в кругу твоего личного бытия, относится к вечным. И ты никогда ничего решительного тут не скажешь», - писал Федин Замятину и Л. Н. Замятиной 21 июня 1932 г. из Сан-Блазиена [5, с. 84]. Да и замятинский творческий метод стал со временем казаться Федину недостаточно органичным и слишком формализированным:

«Первые два кита Замятина язык и образ - плыли из морей Лескова и Ремизова, что в значительной степени предрешало его судьбу трагическую судьбу писателя, как Ремизов, навсегда отдавшегося сражениям с мельницами стиля. $<\ldots>$ он был превосходным бытовиком, его пристрастие к сатире было запущенной болезнью, и если бы он дал волю тому, чем его щедро наделила родная тамбовская Лебедянь, и сдержал бы то, что благоприобрел от далекого Лондона, он поборол бы и другую свою болезнь - формальную изысканность, таящую в себе угрозу бесплодия. Он обладал такими совершенствами художника, которые возводили его 
высоко. Но инженерия его вещей просвечивает сквозь замысел, как ребра человека на рентгеновском экране... Чтобы стать на высшую писательскую ступень, ему недоставало, может быть, только простоты» [8, с. 77-78].

Подобная критика не оценка ученика, переросшего учителя, что не раз встречалось в истории литературы, а неприятие реалистом модернистских творений своего собрата по перу, усиленное неприязнью видного представителя литературного истэблишмента к чуждой ему идеологии писателя-оппозиционера и «невозвращенца».

В последние годы жизни Замятин тоже изменил свое отношение к любимому ученику: симпатия и осознание родства душ и близости творческих миров сменились горьким разочарованием и в личности Федина, и в его творчестве. Нелицеприятная оценка «Похищения Европы» содержится в замятинской статье « $<P y c$ ская литература.IY>». Осудив Федина - литературного функционера, Замятин еще раз подтвердил неизменность своей художнической позиции: литература должна быть внепартийной, свободной, а талантливый писатель - вечно недовольным собой, стремящимся в «завтра» «скифом». Но Федин уже не соответствовал такому типу писателя.

Проведенный анализ выявил разные виды литературных связей, соединявших Замятина с ленинградским литератором в 1920-1930-е гг.: контактные (работа в издательствах, переписка, поддержка Замятина Фединым во время кампании про- тив «попутчиков» 1929 г. и содействие Замятина Федину в получении французской визы, отзывы Замятина о его произведениях), генетические (влияние Замятина на литературные вкусы и творческое развитие писателя-современника). Авторитетный в русских и зарубежных литературных кругах, Замятин популяризировал за рубежом произведения любимого «серапионова брата».

\section{Библиографический список}

1. Галушкин А. Ю. Комментарии // Замятин Е. И. Я боюсь: Лит. критика. Публицистика. Воспоминания. - М. : Наследие, 1999. - С. 282-341.

2. Замятин Е. И. Я боюсь: Лит. критика. Публицистика. Воспоминания / сост. и коммент. А. Ю. Галушкина; подгот. текста А. Ю. Галушкина и М. Ю. Любимовой; вступ. ст. В. А. Келдыша. М. : Наследие, 1999.

3. Каверин В. А. Эпилог. - М. : Моск. рабочий, 1989.

4. «...Мне сейчас хочется тебе сказать...»: Из переписки Б. Пильняка и Е. Замятина с К. Фединым // Лит. учеба. - М., 1990. - № 2. - С. 79-95.

5. (Неопубл. дневники К. Федина 20-30-х гг.)/ Публ. Н. К. Фединой, Н. А. Сломовой; Примечания А. Н. Старкова // Рус. лит. - СПб., 1992. - № 4. - С. 164-181.

6. Полонская Е. Г. Города и встречи. Кн. воспоминаний. - М. : Новое лит. обозр., 2008.

7. «Серапионовы братья» в зеркалах переписки. - М. : Аграф, 2004.

8. Федин К. А. Горький среди нас: Картины лит. жизни. - М., 1967.

9. Федин К. А. Из трех петроградских дневников 1920-1921 годов (публ. Н. К. Фединой и В. В. Перхина) // Рус. лит. - СПб., 1992. - № 4. - С. 139-164.

10. «...Я человек негнущийся и своевольный. Таким и останусь». Письма Е.И. Замятина разным адресатам / Публ. Т. Т. Давыдовой и 
А. Н. Тюрина // Новый мир. - М., 1996. - № 10. - С. 136-159.

\section{Bibliograficheskij spisok}

1. Galushkin A. Ju. Kommentarii // Zamjatin E. I. Ja bojus': Lit. kritika. Publicistika. Vospominanija. - M. : Nasledie, 1999. - S. 282-341.

2. Zamjatin E. I. Ja bojus': Lit. kritika. Publicistika. Vospominanija / sost. i komment. A. Ju. Galushkina; podgot. teksta A. Ju. Galushkina i M. Ju. Ljubimovoj; vstup. st. V. A. Keldysha. - M. : Nasledie, 1999.

3. Kaverin V. A. Jepilog. - M. : Mosk. rabochij, 1989.

4. «...Mne sejchas hochetsja tebe skazat'...»: Iz perepiski B. Pil'njaka i E. Zamjatina s K. Fedinym // Lit. ucheba. - M., 1990. № 2. - S. 79-95.
5. (Neopubl. dnevniki K. Fedina 20-30-h gg.) / Publ. N. K. Fedinoj, N. A. Slomovoj; Primechanija A. N. Starkova // Rus. lit. SPb., 1992. - № 4. - S. 164-181.

6. Polonskaja E. G. Goroda i vstrechi. Kn. vospominanij. - M. : Novoe lit. obozr., 2008.

7. «Serapionovy brat'ja» V zerkalah perepiski. - M. : Agraf, 2004.

8. Fedin K. A. Gor'kij sredi nas: Kartiny lit. zhizni. - M., 1967.

9. Fedin K. A. Iz treh petrogradskih dnevnikov 1920-1921 godov (publ. N. K. Fedinoj i V. V. Perhina) // Rus. lit. - SPb., 1992. - № 4. - S. 139-164.

10. «...Ja chelovek negnushhijsja i svoevol'nyj. Takim i ostanus'». Pis'ma E. I. Zamjatina raznym adresatam / Publ. T. T. Davydovoj i A. N. Tjurina // Novyj mir. - M., 1996. - № 10. - S. 136-159.

(с) Давыцдва Т. Т., 2017. 